\section{Botanical Acquisitions at the British Museum}

THE Department of Botany of the British Museum (Natural History) has received 430 plants collected by Miss Nancy Lindsay and Mrs. A. Fullerton in Iran, principally from the Elburz Mountains, an area which has been little worked. The collection is accompanied by useful notes and by a number of excellent water-colour paintings of the more attractive plants by Miss Lindsay. The Biological Department of the Medical College, St. Bartholomew's Hospital, has presented its botanical herbarium. It is in twelve volumes and contains about eight hundred wellmounted sheets. The collection was apparently got together between 1823 and 1844 ; the majority were collected by T. R. Tuck, although a large number bear the names of the Rev. Prof. J. S. Henslow and C. C. Babington. The Hon. Mrs. de Beaumont has presented the botanical press of A. L. de Jussieu. This interesting historical relic is strongly constructed of mahogany, and resembles a copying press. It takes only a small sheet, such as those of the herbarium of de Jussieu in Paris.

\section{Research in Tropical Medicine}

A Tropical Medical Research Committee has been appointed by the Medical Research Council in consultation with the Colonial Office. The new committee will advise and assist in the direction of such investigations as the Council may be able to promote, whether at home or abroad, into problems of health and disease in tropical climates, and make suggestions generally as to research in this field. The Committee is to be a purely scientific body. It will include representatives of the Colonial Office and of the Liverpool and London Schools of Tropical Medicine, with other members appointed as individual experts in tropical medicine or in different branches of medical science. The following will serve in the first instance: Prof. J. C. G. Ledingham (Chairman), Prof. A. J. Clark, Dr. N. Hamilton Fairley, Prof. W. W. Jameson, Dr. Edward Mellanby, Dr. Muriel Robertson, Sir Leonard Rogers, Dr. H. Harold Scott, Sir Thomas Stanton, Dr. C. M. Wenyon, Prof. Warrington Yorke, and Dr. A. Landsborough Thomson (Secretary).

\section{University of Heidelberg}

Writing with reference to the letter "Heidelberg, Spinoza and Academic Freedom" in Nature of February 29, p. 364, a correspondent states that the solemn presentation of the charter to the Elector Pulatine took place on June 24, 1386, and suggests that this date is an appropriate one to have in mind in connexion with the celebrations to be held in the University of Heidelberg in June next. October 19 , 1936, would appear to bo the opening of the 551st academic year, not the 550th, as stated in Miss Gardiner's letter. It is now stated (The Times, March 3) that the Rector of the University of Heidelberg has sent a letter to universities and academies in Great Britain (with the exception of Cambridge) which have received invitations to participate in the celebrations, withdrawing the invitations. In the course of his letter, the Rector says: "a number of English personalities have to our great regret confused before the public at large their own political opinions with the academic character of the invitation of the University of Heidelberg to its 550th anniversary celebrations and thus deprived the latter of its true meaning. By such action it appears to me that public opinion has been influenced in such a manner as to make it difficult for an Englishman to accept an invitation which has been sent in a friendly spirit".

\section{New Fellows of the Royal Society of Edinburgh}

AT the ordinary meeting of the Royal Society of Edinburgh, held on March 2, the following ordinary fellows were elected: Prof. Thomas Alty, Applied Physics Department, University of Glasgow; Dr. L. E. Bayliss, lecturer in biophysics, University of Edinburgh; Dr. John Berry, research officer, Avon Biological Research, University College, Southampton; Prof. Duncan McC. Blair, Department of Anatomy, University of Glasgow ; Mr. A. J. Brown, lecturer in metallurgy and demonstrator in radiology, Edinburgh Dental Hospital and School ; Sir Robert Bruce, editor of the Glasgow Herald; Dr. William Bryden, lecturer in biology, Technical College, Christchurch, New Zealand; Dr. A. M. Cockburn, assistant, Geological Department, University of Edinburgh; the Right Hon. Thomas Mackay Cooper, His Majesty's Advocate for Scotland; Mr. R. C. Cowan, paper manufacturer, Penicuik; Mr. C. J. T. Cronshaw, managing director, Dyestuffs Group, Imperial Chemical Industries, Ltd., Manchester ; Mr. J. F. Fairweather, fiscal of the Society of Writers to the Signet, Edinburgh; Dr. S. G. Gibbons, naturalist, Fishery Board, Aberdeen; Dr. W. J. Hamilton, lecturer in anatomy and deputy-director, Anatomy Department, St. Thomas's Hospital Medical School, London; Prof. D. K. Henderson, Department of Psychiatry, University of Edinburgh; $\mathrm{Mr}$. Thomas Henderson, secretary to the Educational Institute of Scotland, Edinburgh; Dr. A. Fergus Hewat, secretary, Royal College of Physicians, Edinburgh ; Mr. Donald E. Innes, reader in geology, University of St. Andrews ; Dr. John MeQ. Johnston, pharmacologist, Department of Health for Scotland, Glasgow; Mr. C. H. Kemball, dental surgeon, lecturer on orthodontics, Edinburgh Dental Hospital and School; Dr. P. L. M'Kinlay, medical officer (statistics), Department of Health for Scotland, Clydebank; Dr. John M'Michael, lecturer in physiology, University of Edinburgh ; Dr. William McRae, (lately agricultural adviser to the Government of India and director, Agricultural Research Institute, Pusa, India), Edinburgh; the Very Rev. J. Harry Miller, principal, St. Mary's College, University of St. Andrews; Mr. Francis More, chartered accountant, Edinburgh; Dr. D. Owen Morgan, lecturer in helminthology, Department of Zoology, University of Edinburgh ; Principal W. G. R. Paterson, West of Scotland College of Agriculture, Glasgow ; Dr. D. S. Raitt, naturalist, Fishery Board for Scotland, Aberdeen ; Prof. L. P. W. Renouf, Department of Zoology, 